\title{
Editorial
}

\section{Toxic marine and freshwater algae: an occupational hazard?}

In the summers of 1988 and 1989 tourism along the north coast of the Adriatic Sea was seriously disrupted by an extensive marine algal bloom that fouled Italian and Yugoslav beaches. Unusually widespread blooms of blue-green algae occurred also in many freshwater lakes and reservoirs in the United Kingdom, which experienced exceptionally fine summers in 1989 and 1990. These events raised new alarms over the health hazard of waters containing algal growths to recreational users, workers, and consumers of drinking water, particularly as the toxins produced by certain algal species rank amongst the most potent biotoxins known.

Eutrophication of the Adriatic Sea has been accelerated by waste disposal from the Po river and other sources along the coast, in particular industrial waste, agricultural pesticides, chemical fertilisers, and sewage; a process that has been going on for years. Oxygen depletion of the bottom waters, which was first recognised in 1955, now extends to most of the upper Adriatic. ${ }^{1}$ Although much more needs to be learnt about the causes of algal blooms, eutrophication is believed to favour their development, so massive blooms could become a recurring phenomenon in the Adriatic. Since 1980 exceptional growths of algal blooms have also occurred in the Baltic and North Seas, and sea areas of Japan.

Most toxic marine algae belong to a few species of dinoflagellates and the effects of their toxins, which can be fatal to man exposed through consuming shellfish and fish, are well recognised. ${ }^{2}$ Paralytic and diarrhoeic forms of shellfish poisoning occur world wide, the shellfish having been contaminated by feeding on toxic algal species (for example, Gonyaulax and Dinophysis, or Prorocentrum). Neurotoxic shellfish poisoning occurs in the Gulf of Mexico where blooms of the toxic species responsible, Ptychodiscus brevis, form "red tides"; the effect of wind on the bloom-laden water may liberate aerosols containing toxin that can also irritate the eyes, lips, and respiratory tract of people on the shoreline. ${ }^{3}$ The term "pelagic paralysis" has been suggested for ciguatera and puffer fish poisoning, which, together with paralytic shellfish poisoning, give rise to a similar paralytic syndrome with a common mechanism that acts by blocking voltage gated sodium channels in myelinated and nonmyelinated nerves. ${ }^{4}$ Ciguatera poisoning, a public health hazard common in Pacific and Caribbean islands, ${ }^{5}$ occurs after eating carnivorous fish containing ciguatoxin, and puffer fish poisoning continues to be a deadly hazard to gourmets in Japan. Captain Cook and other early explorers of the oceans recorded, or themselves experienced these fish intoxications in their travels. ${ }^{5}$ The dinoflagellates concerned are benthic, so outbreaks of illness are not dependent upon bloom formation.

The disastrous algal blooms in the Adriatic have been due to non-toxic species of diatoms which produce a copious and slimy mucilage. ${ }^{6}$ The conventional view that blooms of diatoms are invariably non-toxic was dispelled by an outbreak called amnesic shellfish poisoning in Canada in 1987 when a new syndrome of gastrointestinal and neurological disturbances (including chronic memory loss) was attributed to domoic acid produced by blooms of the common marine diatom Nitzschia pungens. ${ }^{78}$

Fishermen may put themselves at risk when they consume portions of their catch: an outbreak of diarrhoeic shellfish poisoning, unrelated to the bloom, occurred in fishermen at one Adriatic port in 1989. Other adverse health effects of marine blooms are speculative, but fishermen may come into direct contact with algal material when it clogs nets and engines and has to be manually removed, or when blooms and scums dry out and have the potential to produce aerosols. Some shellfish fishermen in the Adriatic dive for their catch in shallow waters without using SCUBA gear or protective clothing. Respiratory sensitisation or contact dermatitis have not so far been reported in Adriatic fishermen, but the diatom Fragilaria striatula lyngb has been suspected of causing contact dermatitis in fishermen elsewhere. ${ }^{9}$ Dogger Bank itch, a hazard in North Sea fishermen, is caused by moss animals (sea chervils) and not algae. ${ }^{10}$ To evaluate the potential health hazards of recurrent bloom formation a World Health Organisation working group recommended to the Italian government the setting up of an epidemiological study of the health of Adriatic fishermen who number several thousands. ${ }^{6}$

Eutrophication is also likely to be a key factor in the 
increased production of blue-green algal blooms in inland waters. Reports of ill health associated with these freshwater blooms are mainly from incidents concerning ingestion of water or skin contact with the scum and have been recorded for about 60 years. ${ }^{11} 12$ Some 25 species of blue-green algae have been implicated world wide and a review has recently been published by the United Kingdom National Rivers Authority. ${ }^{11}$ The toxins fall into three main categories: neurotoxins, hepatotoxins, and lipopolysaccharides. As with marine algae the toxins have been detected mainly by intraperitoneal injections of extracts of algal material into laboratory mice. The neurotoxins are mostly produced by species of Anabaena, Aphanizomenon and Oscillatoria and one type (aphantoxins) is similar or identical to saxitoxin, which causes paralytic shellfish poisoning. The hepatotoxins include microcystin and are produced by species of Microcystis, Oscillatoria, and Anabaena. Lipopolysaccharides are normal components of the outer layers of many species and may be the cause of eye and skin irritation and dermatitis in swimmers. Microcystin has been commonly implicated in reports of intoxications involving blue-green algae, such as gastroenteritis in swimmers from accidental ingestion of water, and abnormal liver function and hepatoenteritis in consumers of affected water supplies. ${ }^{11}{ }^{12}$ In 1989 a group of junior soldiers training in canoeing techniques, such as rolling over, in a lake in England containing a toxic Microcystis bloom developed abdominal pain, vomiting, and diarrhoea, with blisters of the mouth and sore throats; two became severely ill after developing atypical pneumonia. ${ }^{13}$ Despite their potential hazard no human deaths have been definitely linked to blue-green algal toxins: people are not usually willing to drink from bloom laden water and, unlike marine toxins, no vectors, like shellfish, exist to concentrate them in the normal food chain. ${ }^{14}$

Seemingly innocuous blooms and scums can rapidly turn toxic for no apparent reason and up to $75 \%$ of all blue-green algal blooms recently tested in the United Kingdom have been found to be toxic. ${ }^{11}$ Warnings to man can be provided by fish kills or deaths of birds, amphibians, livestock, dogs, and other animals that drink the contaminated water. Methods for controlling the development of bluegreen algal blooms are being devised, as are programmes for monitoring waters to detect their spread. ${ }^{11}$

In both marine and freshwater areas workers and recreational users (swimmers, wind surfers, boat enthusiasts, and amateur fishermen, for example) should consider taking special precautions when blooms and scums are visible in the water. The incident with the soldiers also highlighted a potential hazard from inhalation of aerosols of water containing toxic algae; hence respiratory protection may be needed as well as measures to prevent skin contact and ingestion if work in or near affected water is contemplated. Occupations at risk include teachers of water sports, cleaners and maintainers of canals and rivers, water quality testers, wardens and bailiffs, and fish farmers. Owners of inland recreational waters need to establish criteria for closing areas to public users concerned with water sports and similar precautions should be considered at coastal resorts when marine blooms are sighted.

At present our knowledge of the hazards to those whose jobs or recreations bring them into contact with algal blooms is very limited. So far hardly any epidemiological studies of such groups have been performed, or even contemplated, but these will be essential if risk assessments and criteria for advising workers and the public are to be developed. Unfortunately analytical methods for quantifying algal toxins in water are not yet routinely available so estimates of exposure can only be made indirectly at present. The range of illnesses that algae can cause needs confirmation bearing in mind that new algal toxins and unexpected health hazards may continue to be identified. Workers at risk are more easily investigated than recreational users and they should be monitored for eye, skin, pulmonary, and gastrointestinal (especially liver) problems. Also, local or national surveillance of human and animal illnesses suspected of being caused by algae should be established, where appropriate. Health professionals need to be made more aware of the hazards, especially as marine and freshwater algal blooms appear to be becoming more common world wide.

PETER J BAXTER

Department of Community Medicine,

University of Cambridge Clinical School,

Addenbrooke's Hospital, Cambridge CB2 $2 Q Q$

1 Clarke RB. Marine pollution. Oxford: Clarendon Press, 1989.

2 World Health Organisation. Environmental health criteria 37. Aquatic (marine and freshwater) biotoxins. Geneva: WHO, 1984.

3 Pierce RH. Red tide (Ptychodiscus brevis) toxin aerosols: a review. Toxicon 1986;24:955-65.

4 Mills AR, Passmore R. Pelagic paralysis. Lancet 1988;i:161-4.

5 Ruff TA. Ciguatera in the Pacific: a link with military activities. Lancet 1989;i:201-5.

6 World Health Organisation. WHO working group on health impact of human exposure to recreational marine waters. Rimini: WHO, 1990.

7 Perl TM, Bedard L, Kosatsky T, et al. An outbreak of toxic encephalopathy caused by eating mussels contaminated with domoic acid. N Eng J Med 1990;322:1775-80.

8 Teitelbaum JS, Zatorre RJ, Carpenter S, et al. Neurological sequelae of domoic acid intoxication due to the ingestion of contaminated mussels. $N$ Eng J Med 1990;322:1781-7.

9 Fraser JH, Lyell A. Dogger Bank itch. Lancet 1963;i:61.

10 Newhouse ML. Dogger Bank itch: survey of trawlermen. Lancet 1966;1:1142-5.

11 National Rivers Authority. Toxic blue-green algae. London: National Rivers Authority, 1990.

12 Codd GA, Bell SG, Brooks WP. Cyanobacterial toxins in water. Water Science and Technology 1989;21:1-13.

13 Turner PC, Gammie AJ, Hollinrake K, Codd GA. Pneumonia associated with contact with Cyanobacteria. BMJ 1990; 300:1440-1.

14 Gorham PR, Carmichael WW. Hazards of freshwater bluegreen algae (Cyanobacteria). In: Lembi CA, Waaland JR, eds. Algae and human affairs. Cambridge: Cambridge University Press, 1988. 